\title{
Comparative Study of Levels of Trace Metals in Airborne Particulates in Some Cities of the Niger Delta Region of Nigeria
}

\author{
Uno, U. A. ${ }^{1}$, Ekpo, B. O. ${ }^{2}$, Etuk, V. E. ${ }^{3}$, Etuk, H. S. ${ }^{4} \&$ Ibok, U. J. ${ }^{2}$ \\ ${ }^{1}$ Department of Chemical Sciences, Cross River University of Technology Calabar, Nigeria \\ ${ }^{2}$ Environmental and Petroleum Geochemistry Research Group (EPGR), University of Calabar, Nigeria \\ ${ }^{3}$ Department of Chemical Engineering, University of Uyo, Akwa Ibom State, Nigeria \\ ${ }^{4}$ Department of Chemistry, University of Uyo, Akwa Ibom State, Nigeria \\ Correspondence: Ekpo, B. O., Environmental and Petroleum Geochemistry Research Group (EPGR), \\ Department of Pure and Applied Chemistry, University of Calabar, P. M. B. 3766, Calabar, C. R., Nigeria. E-mail: \\ basseyekpo10@yahoo.com; baekpo@gmail.com
}

Received: March 29, 2012 Accepted: April 20, 2012 Online Published: December 25, 2012

doi:10.5539/ep.v2n1p110 URL: http://dx.doi.org/10.5539/ep.v2n1p110

\begin{abstract}
This study measured and compared the levels of trace elements ( $\mathrm{Pb}, \mathrm{Hg}, \mathrm{Cr}, \mathrm{Ni}, \mathrm{V}, \mathrm{Cu}, \mathrm{Cd}, \mathrm{Mn}, \mathrm{Fe}, \mathrm{Zn}, \mathrm{Co}$, and As) in airborne Suspended Particulate Matter (SPM) $\left(\mathrm{PM}_{10}\right)$ collected between July-September, 2005 and January-March, 2006 at four major cities (Calabar, Eket, Aba and Port Harcourt) in the Niger delta region of Nigeria. The SPM concentrations varied from $27.72 \pm 11.33 \mu \mathrm{g} / \mathrm{m}^{3}$ in Calabar to $75.50 \pm 25.60 \mu \mathrm{g} / \mathrm{m}^{3}$ in $\mathrm{Aba}$. Atomic Absorption Spectroscopy (AAS) results show that the air basin at all sites contain concentrations of elements $(\mathrm{Pb}, \mathrm{Hg}, \mathrm{Cr}, \mathrm{Ni}, \mathrm{V}, \mathrm{Cu}, \mathrm{Cd}, \mathrm{Mn}, \mathrm{Co}$ and $\mathrm{As})<15 \mu \mathrm{g} / \mathrm{m}^{3}$. Higher concentration of Fe $\left(41.26 \pm 9.84 \mu \mathrm{g} / \mathrm{m}^{3}\right)$ was recorded at Calabar and of $\mathrm{Zn}\left(39.76 \pm 6.15 \mu \mathrm{g} / \mathrm{m}^{3}\right)$ and $\left(22.91 \pm 6.26 \mu \mathrm{g} / \mathrm{m}^{3}\right)$ at Aba and Port Harcourt respectively. Paired independent t-test at $\mathrm{p} \leq 0.05(\mathrm{df}=34, \mathrm{n}=36)$ confirmed significant seasonal variations in the concentrations of the metals with greater concentrations during the dry season. Enrichment factor (EF) analysis was adopted to identify the sources and their contributions to particulate matter. Our results revealed that the background atmosphere in the studied cities was highly affected by anthropogenic pollution, in the order $\mathrm{PH}>\mathrm{Aba}>$ Eket $>$ Calabar, and demonstrated that high heavy metal concentrations occurred but with significant EF values during the dry season. The present study provides base line information about the region. The results are useful for effective environmental pollution monitoring in the in the Niger Delta air basin.
\end{abstract}

Keywords: trace metals, airborne particulates, Niger delta, Nigeria

\section{Introduction}

Nigeria is ranked the sixth oil producing country in the world with a production capacity of about 1.3 million barrels per day (Usman, 2007). The Niger Delta region from where this oil is obtained is an area of intensive exploitation and exploration of petroleum resources. This has attracted rapid industrialization and urbanization with its attendant traffic intensity. Studies have shown that the occurrence of pollutants in excess of natural loads in most parts of the Niger Delta region of southern Nigeria has become a problem of increasing concern (World Bank, 1995). Globally, in recent decades, it has been found that the number and intensity of anthropogenic sources have increased the overall environmental trace element concentration (Koch \& Retard, 2001). Trace metals may be introduced into the crude oil while they are being transported from oil wells to processing sites and storage tanks. A number of trace metals may be naturally associated with crude oil during the process of formation of the oil. The presence of trace metals in crude oil and other bituminous substances have been reported (Osibanjo et al., 1984). Metallic compounds in crude oils include metalloporphrin chelates, transition metals complexes, organomettallic compounds, carbonyl acid salts of polar functional groups and other colloidal mineral (Achi \& Shide, 2004). Ngwadinigwe and Nworgu (1999) have reported on the concentrations of Na, V, $\mathrm{Fe}, \mathrm{Ca}, \mathrm{K}, \mathrm{Mg}, \mathrm{Ni}, \mathrm{Zn}$ and higher $\mathrm{V} / \mathrm{Ni}$ ratio in some crude oils from Bonny, Brass, Imo River, Yorla and Elwa oil fields within Niger delta region. Gao et al. (1992) have reported that during long-range transport, dust aerosols carry large quantities of mineral particulates as well as anthropogenic air pollution to remote regions.

Among airborne pollutants are trace elements such as $\mathrm{Cd}, \mathrm{Pb}, \mathrm{Sb}$, and $\mathrm{Zn}$ associated with suspended particulates 
from a variety of pollution emission sources. The exposure of a large population to such non-degradable and toxic substances has been shown to have large impact on human health and the ecosystem (Forsberg, 2005). The airborne particulates and related trace metals have been linked with both acute and chronic adverse health effects which mostly include respiratory diseases, lung cancer, heart diseases and damage to other organs (Prieditis \& Adamson, 2002; Magas et al., 2007; Wild et al., 2009).

In order to gain information on trace metals in the atmospheric environment of the Niger delta region of Nigeria, we carried out sampling of SPM at four major cities in the Niger delta over a period of one year (July-September, 2005 representing dry season and January-March, 2006 representing wet season. Seasonal sampling intervals provided sufficient materials and detailed information to assess atmospheric composition and anthropogenic trace metal pollution in this region. This paper presents the results of trace element analyses of those samples. The main purposes of this work were to (1) provide baseline concentrations of heavy metals in the atmosphere of Niger delta region and expand the database for this regions. (2) determine the seasonal variability in the levels of the trace elements for comparison and (3) determine their enrichment factors of the elements and possible sources of pollution in the areas.

\section{Study Area}

Four major cities namely; Calabar, Aba, Port Harcourt (PH) and Eket in Niger Delta region of Nigeria were selected for this study. Each selected city has its unique characteristics which can be replicated across the region. The cities are from states which form a contiguous land mass and are located in the eastern flank of the Niger delta region of Nigeria as shown in Figure 1.

The criteria for considering these cities are: Calabar is generally pollution "free" with no serious petroleum activities. Although Calabar is not heavily industrialized, it has moderate traffic density and farming activities. Aba is a highly urbanized, heavily industrialized and big commercial city with a heavy traffic density with little petroleum activity. Eket town is characterized by heavy petroleum activities-gas flaring, oil exploration and production by Exxon Mobil with a low traffic density. It is not a commercial town. Port Harcourt is a large commercial city, highly urbanized and faced with a heavy traffic density, bush burning and industrialization. It is characterized by heavy petroleum exploration and exploitation activities with extensive gas flaring. In each city, the sites selected were located at least 300 metres from main roads and densely populated areas. The direction of the wind was also considered in the selection of study sites. Site selection for this study took into consideration the reproducibility of results and other environmental factors such as accessibility of sites, availability and suitability of open spaces, areas with minimal local influence from traffic as well as industrial activities and wind direction. The descriptions of sampling sites with geographical coordinates are shown in Table 1 while map showing the selected study sites is shown in Figure 1.

\section{Sampling and Analysis}

Composite samples of ambient air were collected hourly at each of the study sites for six hours between 10.00 am and 6:00 pm in the months of July-September, 2005 representing dry season and January-March, 2006 representing the wet season. All the SPM samples were collected on a German quartz fibre filters with a diameter of $47 \mathrm{~mm}$ and pore size of $1.0 \mu \mathrm{m}$ which was previously annealed for about 8 hours at $500{ }^{\circ} \mathrm{C}$ in order to remove potential background contaminants. The filter holders were protected with a rainproof cover. Electric power to run the vacuum pumps was supplied by a 2 KVA generating system placed 300 meters away from sampling point. The pumps were equipped with an automatic air flow meter, calibrated with an accuracy of $\pm 1.5 \%$ and set at an average flow rate of $1.5 \mathrm{~m}^{3}$ per minute (under local pressure). This was done in consideration of the low SPM background. The air volume for each sample was calibrated to standard sea level pressure (1013 mbar) using the average pressure value (which was automatically measured every 20 mins) during each sampling period. The duration of each sampling period was set to one hour. After sampling, the filters were changed and individually placed into pre-cleaned in aluminum foil for transport and subsequent analysis. Reweighing of the filter paper immediately after sampling under carefully controlled conditions gave a direct measurement of the level of suspended particulate matter as $\mathrm{PM}_{10}$. 
Table 1. Location of sampling sites in the Niger delta region of Nigeria

\begin{tabular}{|c|c|c|c|c|c|c|}
\hline $\mathrm{S} / \mathrm{N}$ & State & City & Code & Coordinates & Location & Description \\
\hline 1 & $\begin{array}{l}\text { Cross } \\
\text { River }\end{array}$ & Calabar & CAQI & $\begin{array}{l}5^{0} 01.479 \mathrm{~N} \\
8^{0} 19.878 \mathrm{E}\end{array}$ & $\begin{array}{l}\text { Located about } 1 \mathrm{~km} \text { east } \\
\text { of CFTZ, cal. }\end{array}$ & $\begin{array}{c}\text { Open filed in an undeveloped } \\
\text { plot. Little vehicular } \\
\text { emission. }\end{array}$ \\
\hline 2 & $\begin{array}{l}\text { Akwa } \\
\text { Ibom }\end{array}$ & Eket & EAQ2 & $\begin{array}{l}4^{0} 34.956 \mathrm{~N} \\
7^{0} 57.798 \mathrm{E}\end{array}$ & Esit Urua Ekit Eket LGA & $\begin{array}{l}\text { Open field. No bush burning } \\
\text { activities. Little vehicular } \\
\text { traffic. }\end{array}$ \\
\hline 3 & Abia & Aba & AAQ3 & $\begin{array}{c}15^{0} 03.29 \mathrm{~N} \\
7^{0} 19.18 \mathrm{E}\end{array}$ & $\begin{array}{c}\text { Around ICS power } \\
\text { generation plant. Alaoji } \\
\text { Road, Aba }\end{array}$ & $\begin{array}{l}\text { Open area. No bush burning. } \\
\text { Little vehicular emission. }\end{array}$ \\
\hline 4 & Rivers & $\begin{array}{l}\text { Port } \\
\text { Harcourt }\end{array}$ & PAQ4 & $\begin{array}{l}4^{0} 50.535 \mathrm{~N} \\
7^{0} 15.245 \mathrm{E}\end{array}$ & $\begin{array}{l}\text { Near Afam Power } \\
\text { station, } \mathrm{PH}\end{array}$ & $\begin{array}{l}\text { Open field. No bush burning } \\
\text { activities. Little vehicular } \\
\text { emission. }\end{array}$ \\
\hline
\end{tabular}

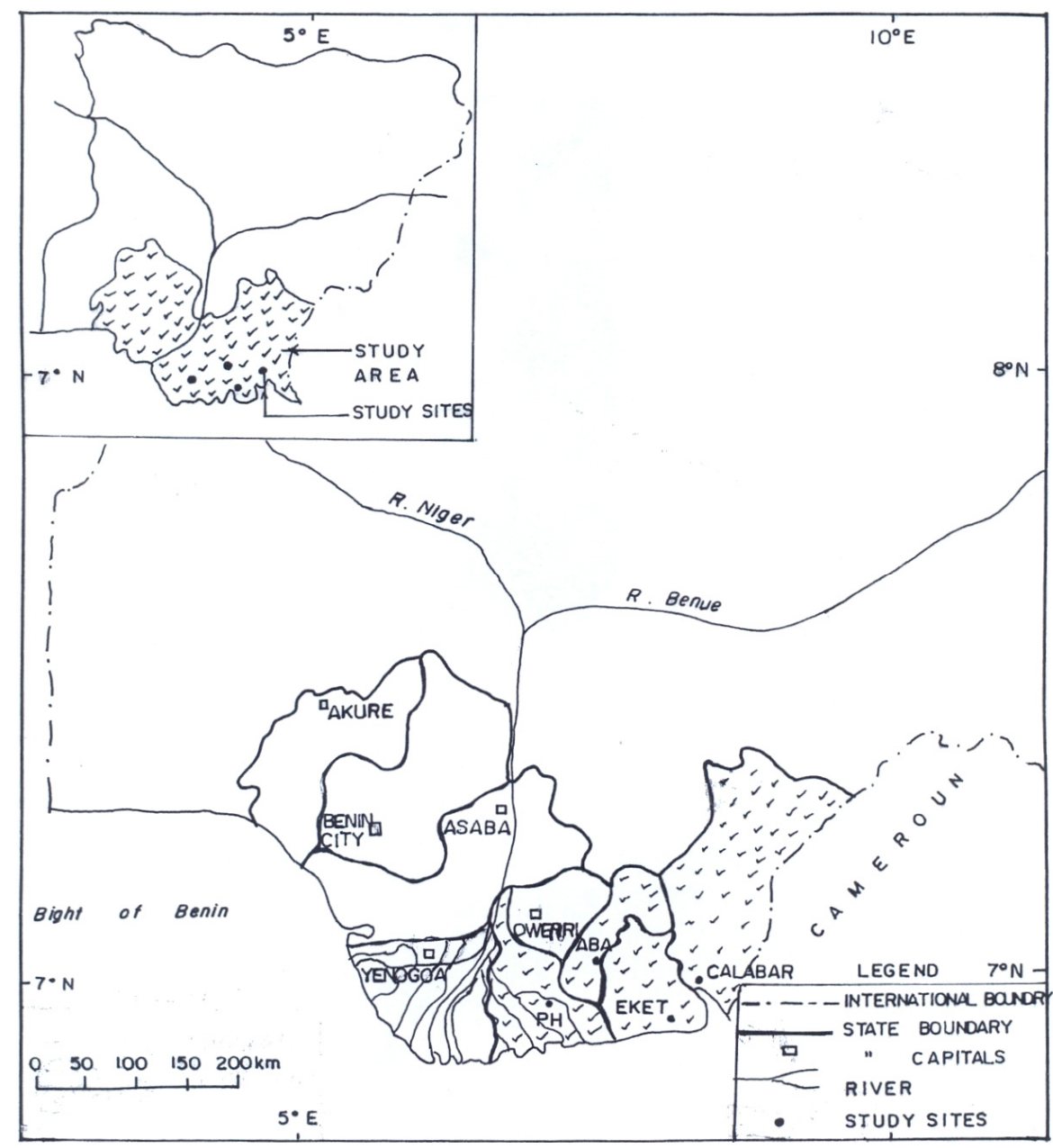

Figure 1. Location of study area on the map of Niger Delta region

\section{Method of Analysis}

In this study, the quantitative elemental analyses of the SPM samples (filters) were performed using atomic absorption spectrophotometer (Perkin Elmer 2380). Filters were dissolved with suprapure $\mathrm{HNO}_{3}$ and $\mathrm{HF}$ 
(ANALA grade) at $150-190{ }^{\circ} \mathrm{C}$ in polytetrafluoroethylene screw-top bombs. After digestion, the dust on the Teflo $^{\text {TM }}$ filters was totally dissolved. The solution was filtered and the filtrate diluted to $30 \mathrm{~cm}^{3}$ with deionized water. The blank filters were also digested and measured, following the same procedures as for the SPM samples, showing very low concentrations. The blank background values were subtracted from the measured results. The levels of the trace metals in the filtrate were determined using AAS.

\section{Results and Discussion}

\subsection{PM 10 Concentrations}

The statistical distribution parameters for SPM $\left(\mathrm{PM}_{10}\right)$ and trace metals $(\mathrm{Cd}, \mathrm{Cr}, \mathrm{Cu}, \mathrm{Fe}, \mathrm{Mn}, \mathrm{Pb}, \mathrm{Ni}$ and $\mathrm{Zn})$ for the study areas are given in Table 2. The particulate matter concentrations varied from $13.20-58.62 \mu \mathrm{g} / \mathrm{m}^{3}$ in Calabar, 20.69-83.76 $\mu \mathrm{g} / \mathrm{m}^{3}$ in Eket, $31.13-99.86 \mu \mathrm{g} / \mathrm{m}^{3}$ in PH and $25.63-104.30 \mu \mathrm{g} / \mathrm{m}^{3}$ in Aba. The mean $\mathrm{PM}_{10}$ concentration was highest at Aba and lowest at Calabar with higher concentrations during dry season (Figure 2). The mean values in the range $27.72 \pm 11.33-75.50 \pm 25.60$ are 9-4 folds respectively lower than the value of 250 $\mu \mathrm{g} / \mathrm{m}^{3}$ annual average stipulated by the national air quality regulating agency (FEPA, 1991) and around 2 times higher than the annual $\mathrm{PM}_{10}$ air quality guideline (AQG) $\left(20 \mu \mathrm{g} / \mathrm{m}^{3}\right)$ set by the World Health Organization (WHO, 2006). Apart from petroleum exploration and exploitation activities, diesel vehicle exhaust is also responsible for emitting particulate matter $\left(\mathrm{PM}_{10}\right)$ in large amounts.

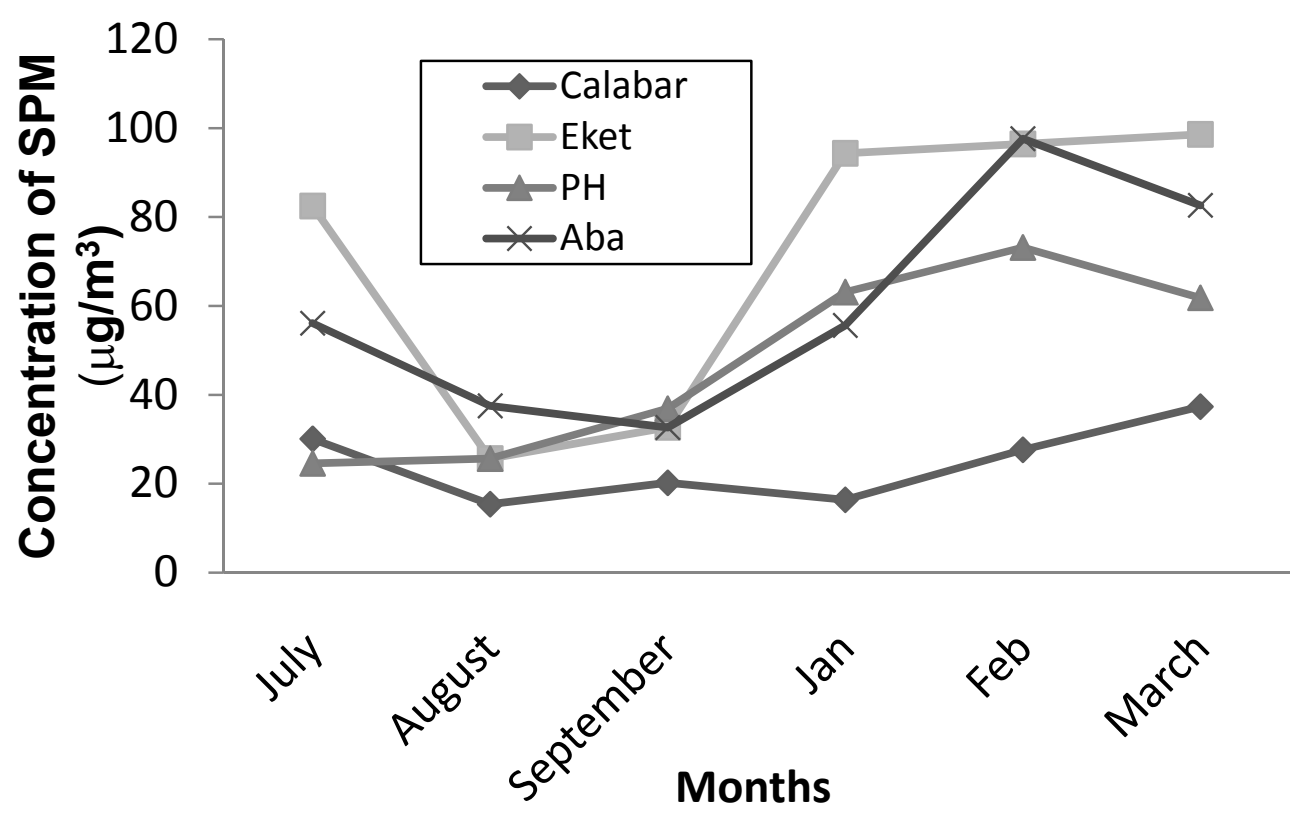

Figure 2. Mean monthly levels of trace metals in SPM from major cities in Niger delta region

\subsection{Mean Flux of Trace Metals in SPM}

Concentrations of trace metal elements in the SPM show large variability from September, 2005 for dry season to January-March, 2006. The average, standard deviation (SD), minimum (Min) and maximum (Max) values of trace metal concentrations in SPM of the Niger delta air basin are shown in Table 2. The mean level of $\mathrm{Hg}$ was lowest at all the locations followed by cadmium. The mean level of Fe $\left(41.26 \pm 9.80 \mu \mathrm{g} / \mathrm{m}^{3}\right)$ was highest in Calabar followed by $\mathrm{Pb}\left(11.25 \pm 5.86 \mu \mathrm{g} / \mathrm{m}^{3}\right)$. At Aba, $\mathrm{Zn}$ level $\left(39.76 \pm 6.15 \mu \mathrm{g} / \mathrm{m}^{3}\right)$ was highest followed by $\mathrm{Pb}(15.77$ $\left.\pm 4.01 \mu \mathrm{g} / \mathrm{m}^{3}\right)$ while at Eket, Pb level $\left(11.83 \pm 2.28 \mu \mathrm{g} / \mathrm{m}^{3}\right)$ was highest followed by $\mathrm{Cu}\left(7.26 \pm 1.67 \mu \mathrm{g} / \mathrm{m}^{3}\right) . \mathrm{At}$ Port Harcourt, Zn level $\left(22.91 \pm 6.26 \mu \mathrm{g} / \mathrm{m}^{3}\right)$ was highest while $\mathrm{Pb}\left(14.19 \pm 2.99 \mu \mathrm{g} / \mathrm{m}^{3}\right)$ being the second. The mean levels of $\mathrm{Zn}$ at Port Harcourt and $\mathrm{Aba}, \mathrm{Fe}$ at Calabar and $\mathrm{Pb}$ at all the locations are significant. 


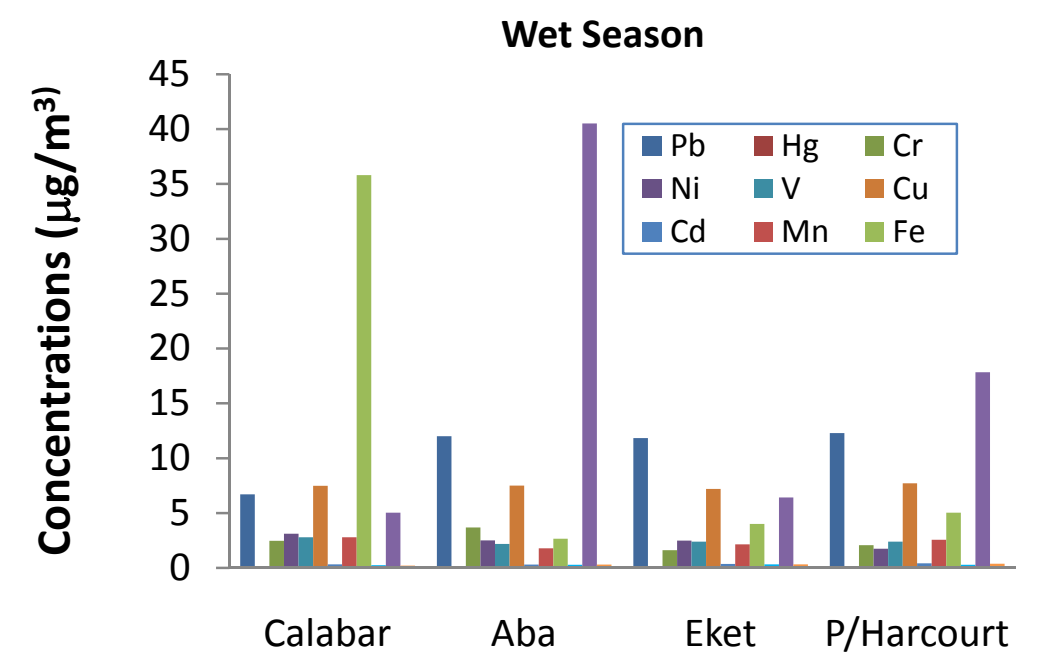

\section{Sampling Cities}

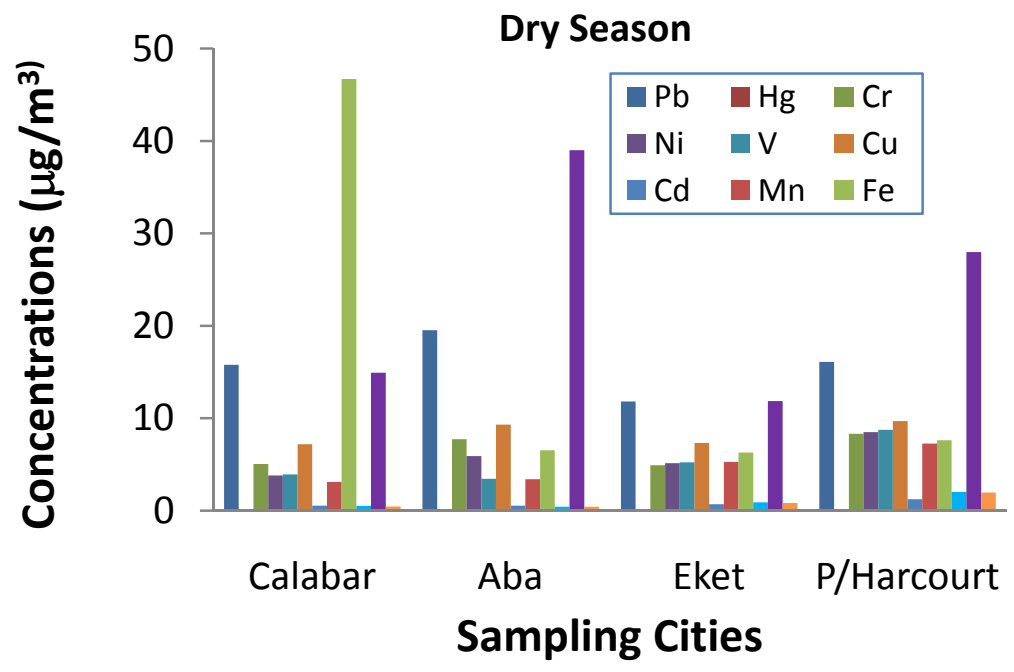

Figure 3. Seasonal variation in the levels of trace metals in SPM from major cities in Niger delta region

\subsection{Spatial-Seasonal Variability in Metal Fluxes in SPM}

The mean levels of trace metals in SPM in the atmosphere for the wet and dry seasons for each location are presented in Table 3 and Figure 3. Some of the trace metals identified in the SPM in the atmosphere within the study area showed spatial variation due to industrial activities at each location. This observation is not surprising and is consistent with that of Uzoekwe et al. (2008) who ascribed the observed spatial variation in the data to differences in the levels of industrial activities at the different monitoring sites. A report by WHO (2000) has also confirmed the fact that ambient levels of atmospheric pollutants depend upon strength of the source, efficiency of their dispersion and other meteorological conditions like turbulence and inversion. Higher concentrations of the elements were observed in the dry season except $\mathrm{Cu}$ at Eket and Calabar, $\mathrm{Pb}$ at Eket and $\mathrm{Zn}$ at Aba. Results of a paired t-test at $\mathrm{P} \leq 0.05(\mathrm{df}=34, \mathrm{n}=36)$ reveal that the seasonal variations in levels of the elements were all significant (Table 3) except that of $\mathrm{Pb}$ at Calabar, $\mathrm{Cu}$ at Calabar and Eket and $\mathrm{Zn}$ at $\mathrm{Aba}$. McDonald and Duncan (1979) in a study on the atmospheric levels of trace elements in the atmosphere in Glasgow listed rain as one of the weather parameters which persistently has the greatest effect on particulate levels which tends to cleanse the atmosphere. In Benin City in Nigeria, a study on the temporal and spatial variations of benzene in the atmosphere revealed that the levels of benzene were higher in the dry season (Olumayede et al., 2008). This observation is in agreement with that of Uzoekwe et al. (2008) in a similar study on $\mathrm{NO}_{2}$ in Gelegele community in Edo State, Nigeria, and is consistent with our findings. 
Table 2. Mean levels of trace metals in SPM. Values are given as mean \pm SD and values in bracket represent ranges $\left(\mu \mathrm{g} / \mathrm{m}^{3}\right)$

\begin{tabular}{lllll}
\hline & Calabar & Aba & Eket & P/Harcourt \\
\hline $\mathrm{SPM}$ & $27.72 \pm 11.33$ & $75.50 \pm 25.60$ & $49.65 \pm 22.07$ & $61.23 \pm 23.36$ \\
& $(13.20-58.62)$ & $(25.63-104.30)$ & $(20.69-83.76)$ & $(31.13-99.86)$ \\
$\mathrm{Pb}$ & $11.25 \pm 5.86$ & $15.77 \pm 4.01$ & $11.83 \pm 2.28$ & $14.19 \pm 2.99$ \\
& $(4.9-22.4)$ & $(9.83-20.6)$ & $(8.2-16.2)$ & $(9.42-17.25)$ \\
$\mathrm{Hg}$ & $0.03 \pm 0.01$ & $0.03 \pm 0.01$ & $0.03 \pm 0.01$ & $0.04 \pm 0.02$ \\
& $(0.02-0.06)$ & $(0.01-0.04)$ & $(0.01-0.06)$ & $(0.02-0.08)$ \\
$\mathrm{Cr}$ & $3.37 \pm 1.55$ & $5.70 \pm 2.28$ & $3.27 \pm 1.96$ & $5.20 \pm 3.18$ \\
& $(1.65-6.54)$ & $(2.74-9.62)$ & $(0.56-6.65)$ & $(1.67-8.84)$ \\
$\mathrm{Ni}$ & $3.47 \pm 0.65$ & $4.20 \pm 1.97$ & $3.81 \pm 1.84$ & $5.12 \pm 3.46$ \\
& $(2.24-4.80)$ & $(1.68-7.73)$ & $(1.34-7.24)$ & $(1.1-9.43)$ \\
$\mathrm{V}$ & $3.36 \pm 0.75$ & $2.82 \pm 0.82$ & $3.82 \pm 1.89$ & $5.57 \pm 3.39$ \\
& $(1.96-4.56)$ & $(1.63-4.26)$ & $(1.1-8.24)$ & $(1.45-10.45)$ \\
$\mathrm{Cu}$ & $7.35 \pm 1.65$ & $8.40 \pm 1.17$ & $7.26 \pm 1.67$ & $8.71 \pm 1.48$ \\
& $(3.87-9.32)$ & $(6.21-9.96)$ & $(3.87-9.65)$ & $(5.63-10.24)$ \\
$\mathrm{Cd}$ & $0.44 \pm 1.65$ & $0.42 \pm 0.15$ & $0.54 \pm 0.26$ & $0.82 \pm 0.50$ \\
& $(3.87-9.32)$ & $(0.18-0.68)$ & $0.16-0.99$ & $(0.14-1.86)$ \\
$\mathrm{Mn}$ & $2.79 \pm 0.71$ & $2.60 \pm 1.01$ & $3.71 \pm 2.08$ & $4.91 \pm 2.40$ \\
& $(1.34-4.00)$ & $(1.45-4.45)$ & $(1.32-7.23)$ & $(2.16-7.75)$ \\
$\mathrm{Fe}$ & $41.26 \pm 9.84$ & $4.60 \pm 2.12$ & $5.15 \pm 2.15$ & $6.32 \pm 1.53$ \\
& $(24.5-58.6)$ & $(1.46-7.67)$ & $(2.34-8.45)$ & $(3.56-8.86)$ \\
$\mathrm{Zn}$ & $9.98 \pm 6.03$ & $39.76 \pm 6.15$ & $9.13 \pm 4.93$ & $22.91 \pm 6.26$ \\
& $(3.24-22.24)$ & $(30.24-50.39)$ & $(4.68-22.2)$ & $(14.4-38.2)$ \\
$\mathrm{Co}$ & $0.38 \pm 0.16$ & $0.35 \pm 0.09$ & $0.62 \pm 0.39$ & $1.16 \pm 0.95$ \\
& $(0.16-0.76)$ & $(0.21-0.49)$ & $(0.12-1.35)$ & $(0.16-2.68)$ \\
$\mathrm{As}$ & $0.33 \pm 0.18$ & $0.37 \pm 0.09$ & $0.58 \pm 0.39$ & $1.17 \pm 0.84$ \\
& $(0.16-0.96)$ & $(0.24-0.54)$ & $(0.1-1.56)$ & $(0.26-2.52)$ \\
\hline
\end{tabular}

$\mathrm{SD}=$ Standard deviation

\subsection{Sources of Trace Metals in Niger Delta Air Basin}

To determine whether certain trace metals and elements were present in high concentrations relative to their concentrations in the earth's crust, an enrichment factor was calculated. In the present study enrichment factor was used to assess the level of contamination and the possible anthropogenic impact in the Niger delta region. To identify anomalous metal concentration, geochemical normalization of the heavy metals data to a conservative element, such as $\mathrm{Al}, \mathrm{Fe}$, and $\mathrm{Si}$ have been employed. Several authors have successfully normalized trace and heavy metal contaminants in sediments and atmosphere (Schiff \& Weisberg, 1999; Baptista-Neto et al., 2000; Mucha et al., 2003; Kim et al., 2000; Wu et al., 2009) relative to a conservative element (Fe and $\mathrm{Al}$ ) that is dominantly lithogenous in origin. In this study Fe was used as a conservative tracer to differentiate natural from anthropogenic components. According to Ergin et al. (1991), Wu et al. (2009), and Dubey et al. (2012), the metal enrichment factor (EF) is defined as follows:

$\mathrm{EF}=(\mathrm{M} / \mathrm{Fe})_{\text {sample }} /(\mathrm{M} / \mathrm{Fe})_{\text {background, }}$,

where $\mathrm{EF}$ is the enrichment factor,

$(\mathrm{M} / \mathrm{Fe})_{\text {sample }}$ is the ratio of metal and Fe concentration of the sample,

$(\mathrm{M} / \mathrm{Fe})_{\text {background }}$ is the ratio of metal and $\mathrm{Fe}$ concentration of a background. 
Table 3. Seasonal variation of mean levels of trace metals $\left(\mu \mathrm{g} / \mathrm{m}^{3}\right)$ in SPM from major cities in Niger delta region

\begin{tabular}{|c|c|c|c|c|c|c|c|c|}
\hline & Wet & Dry & $\mathrm{P} \leq 0.05$ & Rmk & Wet & Dry & $\mathrm{P} \leq 0.05$ & Rmk \\
\hline & \multicolumn{4}{|c|}{ Calabar } & \multicolumn{4}{|c|}{ Aba } \\
\hline $\mathrm{Pb}$ & 6.71 & 15.79 & 0.000 & Sig & 12.01 & 19.53 & 0.000 & Sig \\
\hline $\mathrm{Hg}$ & 0.02 & 0.03 & 0.000 & Sig & 0.02 & 0.03 & 0.000 & Sig \\
\hline $\mathrm{Cr}$ & 2.46 & 5.04 & 0.000 & Sig & 3.68 & 7.73 & 0.000 & Sig \\
\hline $\mathrm{Ni}$ & 3.12 & 3.82 & 0.001 & Sig & 2.50 & 5.90 & 0.001 & Sig \\
\hline $\mathrm{V}$ & 2.79 & 3.93 & 0.001 & Sig & 2.19 & 3.44 & 0.001 & Sig \\
\hline $\mathrm{Cu}$ & 7.49 & 7.20 & 0.598 & NS & 7.51 & 9.30 & 0.000 & Sig \\
\hline $\mathrm{Cd}$ & 0.32 & 0.55 & 0.000 & Sig & 0.30 & 0.54 & 0.000 & Sig \\
\hline $\mathrm{Mn}$ & 2.79 & 3.11 & 0.183 & Sig & 1.78 & 3.41 & 0.000 & Sig \\
\hline $\mathrm{Fe}$ & 35.81 & 46.70 & 0.000 & Sig & 2.66 & 6.54 & 0.001 & Sig \\
\hline Co & 0.25 & 0.51 & 0.000 & Sig & 0.29 & 0.42 & 0.000 & Sig \\
\hline $\mathrm{Zn}$ & 5.04 & 14.92 & 0.000 & Sig & 40.52 & 39.00 & 0.469 & NS \\
\hline \multirow[t]{2}{*}{ As } & 0.20 & 0.45 & 0.000 & Sig & 0.30 & 0.43 & 0.000 & Sig \\
\hline & \multicolumn{4}{|c|}{ Eket } & \multicolumn{4}{|c|}{ Port Harcourt } \\
\hline $\mathrm{Pb}$ & 11.84 & 11.82 & 0.987 & NS & 12.29 & 16.10 & 0.000 & Sig \\
\hline $\mathrm{Hg}$ & 0.02 & 0.04 & 0.000 & Sig & 0.02 & 0.05 & 0.000 & Sig \\
\hline $\mathrm{Cr}$ & 1.62 & 4.92 & 0.000 & Sig & 2.08 & 8.32 & 0.000 & Sig \\
\hline $\mathrm{Ni}$ & 2.49 & 5.13 & 0.000 & Sig & 1.75 & 8.50 & 0.001 & Sig \\
\hline V & 2.40 & 5.24 & 0.000 & Sig & 2.39 & 8.75 & 0.001 & Sig \\
\hline $\mathrm{Cu}$ & 7.20 & 7.32 & 0.832 & NS & 7.72 & 9.70 & 0.000 & Sig \\
\hline $\mathrm{Cd}$ & 0.36 & 0.71 & 0.000 & Sig & 0.41 & 1.23 & 0.000 & Sig \\
\hline $\mathrm{Mn}$ & 2.15 & 5.27 & 0.000 & Sig & 2.57 & 7.25 & 0.000 & Sig \\
\hline $\mathrm{Fe}$ & 4.01 & 6.29 & 0.001 & Sig & 5.04 & 7.62 & 0.001 & Sig \\
\hline Co & 0.33 & 0.91 & 0.000 & Sig & 0.28 & 2.03 & 0.000 & Sig \\
\hline $\mathrm{Zn}$ & 6.42 & 11.85 & 0.000 & Sig & 17.84 & 27.98 & 0.000 & Sig \\
\hline As & 0.33 & 0.84 & 0.000 & Sig & 0.38 & 1.97 & 0.000 & Sig \\
\hline
\end{tabular}

Rmk = Remark; Sig = Significant; Ns = Not Significant; Df = 34, N = 36

Many authors prefer to express the metal contamination with respect to average shale to quantify the extent and degree of metal pollution (Muller, 1969; Forstner \& Muller, 1973; Taylor \& McLennan, 1995). In this study, the background concentrations of the elements were taken from (Turekian \& Wedepohl, 1961). Figure 4 shows EF values of $\mathrm{Pb}, \mathrm{Hg}, \mathrm{Cr}, \mathrm{Ni}, \mathrm{V}, \mathrm{Cu}, \mathrm{Cd}, \mathrm{Mn}, \mathrm{Fe}, \mathrm{Zn}, \mathrm{Co}$, and As for the four cities. According to Zhang and Liu (2002), EF values between 0.5 and 1.5 indicate the metal is entirely from crustal materials or natural processes, whereas $\mathrm{EF}$ values greater than 1.5 suggest that the sources are more likely to be anthropogenic. An EF value close to unity (less than 5) is considered to indicate a dominant input from rock and soil, while an EF value greater than 10 strongly suggests that the corresponding element originated mainly from other sources (Ferrari et al., 2004). The results of the present study show that all the elements were significantly enriched at all study locations since their EF values are greater than 10 (Figure 4). The highest average $\mathrm{EF}$ is seen for $\mathrm{Cd}, \mathrm{Pb}$ and $\mathrm{Hg}$ with values in decreasing order: $\mathrm{PH}>\mathrm{Aba}>$ Eket while Calabar recorded the least EF for all the elements (Figure 4). The difference in EF values may be due to the difference in the magnitude and input for each metal in the atmosphere and/or the difference in the removal rate of each metal from the air basin. High EF values for these trace and heavy metal have been reported in SPM in ambient air of artisan workshops in Benin city (Okuo \& Okolo, 2011). There are three major anthropogenic sources of trace elements in the atmosphere of the Niger delta of Nigeria: (1) stationary fossil fuel combustion is the major source of $\mathrm{Cr}$, largely from coal combustion, (2) combustion of petroleum products provides the major source of $\mathrm{Ni}$ and $\mathrm{V}$, and the combustion of leaded, low-leaded, and unleaded gasoline continues to be the major source of atmospheric $\mathrm{Pb}$ emissions, and (3) non-ferrous metal production is the largest source of atmospheric $\mathrm{Zn}, \mathrm{Cu}$, As, and Cd (Pacyna \& Pacyna, 2001). Beside these three major sources, some heavy metals have specific sources. For example, waste incineration and the use of phosphate fertilizers in agricultural areas are major sources for Cd (Harmens et al., 2004).

The mean levels of $\mathrm{Pb}$ in air-borne particulates were very significant at all locations as shown in Table 2. Apart from the fact that a lot of petroleum activities go on in the region, the cities selected for the study are major cities with considerable traffic density. Traffic emissions may contribute immensely to the levels of $\mathrm{Pb}$ in the 
atmosphere. The concentration of lead in the natural environment is not high since it is a non-essential element (Ayodele \& Ali, 2007). $\mathrm{Pb}$ is added to gasoline as tetramethylead and tetraethyl lead as an antiknock agent. The metal is released to the atmosphere through the exhausts as lead halides produced by the reaction of tetraethyl lead from gasoline with ozone and other haloalkanes. The emission is through the exhaust of automobile engines using the leaded gasoline as fuel.

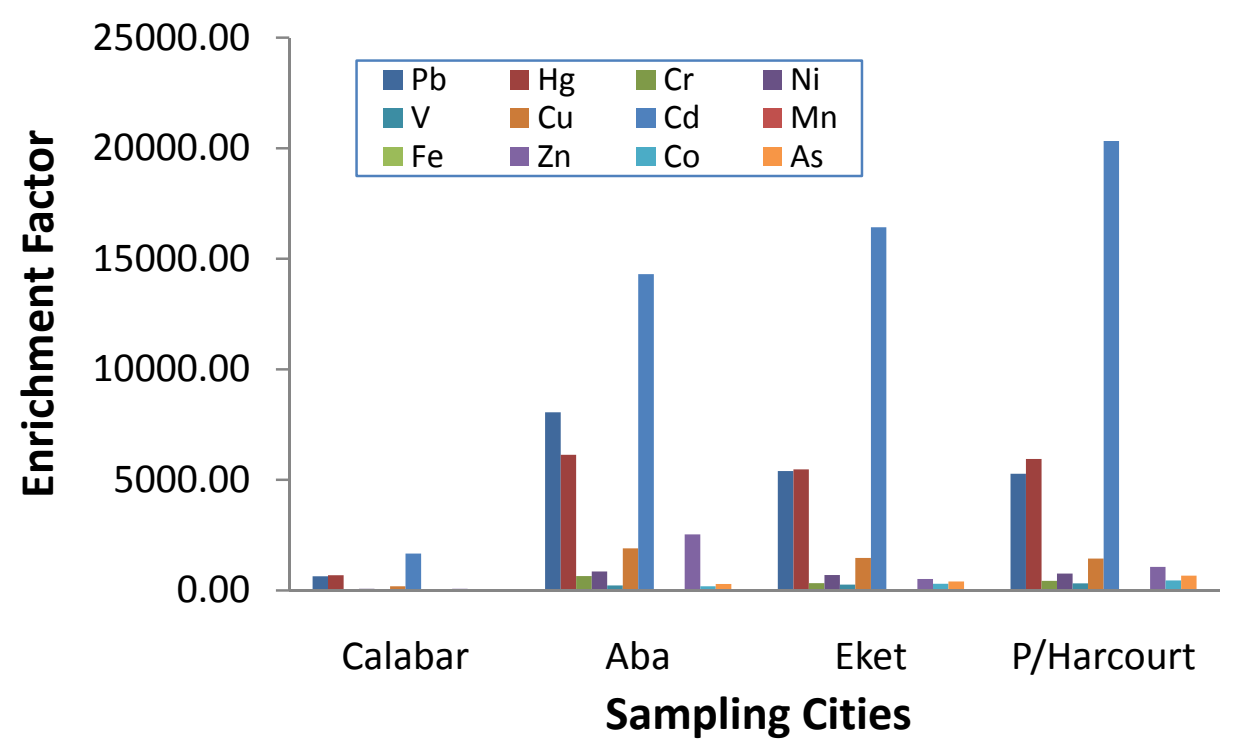

Figure 4. Average enrichment factors of trace elements in SPM at four cities in Niger delta region of Nigeria

The results obtained (Table 2) reveal that the mean level of lead was very significant at the four locations under study. This is probably due to the heavy traffic emission in these cities caused by urbanization and industrialization. In a study conducted in nine different zones of Bombay city, a significant positive correlation was found between air-borne lead and the vehicular (petrol-driven) traffic density counted at the time of sampling (Khandekar et al., 1979). This suggests that automobile exhaust emission may be a prominent source of air-borne lead in the city of Bombay and is consistent with the findings of this study. Moreover, as a result of problems of power supply in the study area, almost all families, traders, industries and other establishments depend on gasoline or diesel driven generators for supply of energy either for domestic or industrial use. The exhaust emissions from these petrol driven power generators may probably contribute to the levels of atmospheric lead in the study area leading to the observed high level of $\mathrm{Pb}$ in the atmosphere.

The mean level of $\mathrm{Fe}\left(41.26 \pm 9.84 \mu \mathrm{g} / \mathrm{m}^{3}\right)$ was found to be highest in Calabar. This is not unexpected considering the level of quarrying activities around Calabar vicinity. The quarries at Awi, Nsan, Okom-Ita, Etamkpini, Mfamosing and the cement factory in Calabar may contribute to the high level of Fe in the Calabar environment. Moreover, major construction works in the capital city as well as the daily activities of iron-mongers, automobile mechanics may release sufficient levels of $\mathrm{Fe}$ into the atmosphere. In a study of $\mathrm{Pb}, \mathrm{Cd}, \mathrm{Zn}, \mathrm{Cu}$, and $\mathrm{Fe}$ in the atmosphere of Greater Bombay, Khandekar et al. (1979) found that air-borne levels of Fe were higher in the city area where major construction works were in progress.

During the period of study, major building and road construction activities including relocation of the cement (UNICEM) factory, transportation of quarry products were observed in Calabar. Iron being the most widely used of all the metals, comprising $95 \%$ of the tonnage of all the metals produced worldwide (Greany, 2005) may have been released into the environment. This was observed by the highest mean concentration of Fe $(0.6622 \pm 0.422$ ppm) compared to $\mathrm{Pb}, \mathrm{Cu}, \mathrm{Cr}$, and $\mathrm{Zn}$ in dust particulates from Calabar Municipality, Nigeria (Ogri et al., 2000). Similarly, Fe had the highest mean level of $2149.25 \pm 173.16 \mu \mathrm{g} / \mathrm{g}$ followed by $\mathrm{Pb}(1.34 \pm 0.44 \mu \mathrm{g} / \mathrm{g})$ in a study of trace metals and total hydrocarbons in soil and bio-data from a seasonal wetland drained by Municipal run-off from Calabar (Ogri et al., 2007).

As observed, the mean levels of $\mathrm{Zn}$ at Port Harcourt $\left(22.91 \pm 6.26 \mu \mathrm{g} / \mathrm{m}^{3}\right)$ and Aba $\left(39.76 \pm 6.15 \mu \mathrm{g} / \mathrm{m}^{3}\right) \mathrm{were}$ higher than those at Calabar and Eket. Zinc may be emitted by aritisanal metal industries which are a common feature in Aba. Panel beaters, tinkers, welders and other mechanics associated with the automobile industry 
release a lot of zinc and other wastes into the atmosphere. Industrial activities such as mining, coal and waste combustion, as well as steel processing may increase the levels of zinc in the environment. Other industrial sources include zinc smelting and electroplating, phosphate fertilizer industry and increasing demand for re-chargeable batteries. In Port Harcourt, industries which may be responsible for the atmospheric zinc level include Pipelines Products and Marketing Company, PPMC at Eleme, Nigerian Fertilizer Company (NAFCON) at Onne and Port Harcourt Refinery Company at Alasa Eleme, Eleme Petrochemical Industry and others sited along the Trans Amadi Industrial Layout (Ekweozor et al., 2003). These industries together with the regular petroleum exploration and exploitation activities may be responsible for the release of zinc and other trace metals in the atmosphere. Meteorological factors like wind direction and speed may also be responsible for the transportation of zinc pollutants from Port Harcourt to other part of the Niger delta.

The low mean levels of $\mathrm{Hg}$ suggest that activities in the production of $\mathrm{Hg}$ are very low in the study area. Industrial effluents may find their way into aquatic environments with a resultant low level in the atmosphere. $\mathrm{Cd}$ is a relatively rare heavy metal (Elinder \& Jarup, 1991). It is widely distributed at low levels in the environment and from present knowledge it is not an essential element for human, animals or plants (FDA, 1993). This perhaps explains its low level observed in this study. The level of Cd may be increased from wear and tear of automobile tyres (Langerweff \& Specht, 1970; Burton \& John, 1977). Vanadium was found at appreciable level in the study area. This may be an indication of petroleum hydrocarbon contamination of the study area (NRC, 1985; Asuquo et al., 1999). Although the levels of these trace elements are relatively low, their enrichment factors indicate sources from anthropogenic input.

\section{Conclusion}

Sampling of SPM for one year (July-September, 2005 for dry season and January-March, 2006 for wet season) has provided information on the levels of trace metals in the atmosphere of Niger delta region and furthers our understanding of anthropogenic pollution in this region.

The particulate matter $\left(\mathrm{PM}_{10}\right)$ concentrations were lower than the value of $250 \mu \mathrm{g} / \mathrm{m}^{3}$ annual average stipulated by the national air quality regulating agency (FEPA, 1991).

The seasonal variations of $\mathrm{Pb}, \mathrm{Hg}, \mathrm{Cr}, \mathrm{Ni}, \mathrm{V}, \mathrm{Cu}, \mathrm{Cd}, \mathrm{Mn}, \mathrm{Fe}, \mathrm{Zn}, \mathrm{Co}$, and As showed high concentrations during dry season than during wet season.

Enrichment factor (EF) analysis proved useful in identifying the sources and their contributions to particulate matter and indicate that that the background atmosphere in the studied cities is highly affected by anthropogenic pollution, in the order $\mathrm{PH}>\mathrm{Aba}>$ Eket $>$ Calabar, and demonstrate that high heavy metal concentrations occur but with significant $\mathrm{EF}$ values during the dry season.

Three major anthropogenic sources of trace elements in the atmosphere of the Niger delta have been identified as: (1) stationary fossil fuel combustion-coal combustion, (2) combustion of petroleum products-combustion of leaded, low-leaded, and unleaded gasoline and (3) non-ferrous metal production, waste incineration and the use of phosphate fertilizers in agricultural areas.

The levels of pollutants obtained in the study have provided baseline information about the regional pollution pattern and intra regional atmospheric cycle of the pollutants.

\section{References}

Achi, S. S., \& Shide, E. (2004). Analysis of trace metals by wet ashing and spectrophotometric techniques of crude oils samples. Journal of Chemical Society of Nigeria, 29(1), 11-14.

Agbozu, I. E., \& Ekweozor, I. K. E. (2004). Heavy metal levels in sediments from lower Taylor Creek in the Niger Delta area of Nigeria. Africa Journal of Science, 5(1), 1043-1049.

Agbozu, I. E., \& Ekweozor, I. K. E. (2001). Heavy metal levels in non-tidal fresh water swamps in the Niger Delta area of Nigeria. Africa Journal of Science, 2, 175-182.

Asuquo, F. E., Ogri, O. R., \& Bassey, E. S. (1999). Distribution of heavy metals and total hydrocarbons in coastal waters and sediments of Cross River State, South East Nigeria. International Journal of Tropical Environment, 2, 229-242.

Ayodele, J. T., \& Ali, Z. N. (2007). Lead and copper in Kaduna street dust particulate matters. Global Journal of Environmental Sciences, 6(2), 99-106.

Baptista-Neto, J. A., Smith, B. J., \& McAllister, J. J. (2000). Heavy metal concentrations in surface sediments in a nearshore environment, Jurujuba Sound, Southeast Brazil. Environ. Pollut., 109, 1-9. 
http://dx.doi.org/10.1016/S0269-7491(99)00233-X

Burton, K. W., \& John, E. (1977). Study of heavy metal concentration in the Rhodda Fawa, South Wales. Water, Air and Soil Pollution, 7, 45-68. http://dx.doi.org/10.1007/BF00283799

Dambo, W. B. (2000). Ecotoxicology of Heavy Metals and Petroleum Related Compounds on the Mangrove Oyster (Crassostrea gasar) from the Lower Bonny Estuary, Nigeria. A Ph. D thesis in Marine Biology, Department of Biological Sciences, Rivers State University of Science and Technology, Port Harcourt, Nigeria.

Dubey, B., Pal, A. K., \& Singh, G. (2012). Trace metal composition of airborne particulate matter in the coal mining and non-mining areas of Dhanbad Region, Jharkhand, India. Atmospheric Pollution Research, 3, 238-246. http://dx.doi.org/10.5094/APR.2012.026

Ekweozor, I. K. E., Dambo, W. B., \& Daka, E. R. (2003). Zinc and cadmium levels in Crassostrea gasar from the lower Bonny Estuary, Nigeria. Journal of Nigerian Environmental Society, 1(1), 31-40.

Elinder, G. G., \& Jarup, L. (1991). Cac174 Cadmium exposure and health risk. Recent findings. Ambo, 25(5), 370-373.

Ergin, M., Saydam, C., Basturk, O., Erdem, E., \& Yoruk, R. (1991). Heavy metal concentrations in surface sediments from the two coastal inlets (Golden Horn Estuary and _Izmit Bay) of the northeastern Sea of Marmara. Chem. Geo., 91, 269-285. http://dx.doi.org/10.1016/0009-2541(91)90004-B

Food and Drug Administration (FDA). (1993). Guidance Document for Cadmium in Shell Fish. Washinton DC: U. S. Food and Drug Administration Publication.

Federal Environmental Protection Agency (FEPA). (1991). National Interim Guidelines and Standards for Industrial Effluents, Gaseous Emissions and Hazardous Wastes in Nigeria. (pp. 1-42). Abuja: Government Press.

Ferrari, C. P., Clotteau, T., Thompson, L. G., Barbante, C., Cozzi, G., Cescon, P., ... Boutron, C. F. (2004). Heavy metals in ancient tropical ice: initial results. Atmospheric Environment, 35, 5809-5815. http://dx.doi.org/10.1016/S1352-2310(01)00347-8

Forsberg, B., \& Hans-Christen, H. (2005). Comparative health impact assessment of local and regional particulate air pollutants in Scandinavia. AMBIO: Journal of the Human Environment, 34(1), 11-19.

Forstner, U., \& Muller, G. (1973). Heavy metal accumulation in river sediments: a response to environmental pollution. Geoforum, 145, 53-61. http://dx.doi.org/10.1016/0016-7185(73)90006-7

Gao, Y., Arimoto, R., Duce, R. A., Lee, D. S., \& Zhou, M. Y. (1992). Input of atmospheric trace elements and mineral matter to the Yellow Sea during the spring of a low-dust year. Journal of Geophysical Research, 97 (D4), 3767-3777. http://dx.doi.org/10.1029/91JD02686

Greany, K. M. (2005). An Assessment of Heavy Metal Contamination in the Marine Sediments of Las Parlas Achipelego, Gulf of Panama. Edinburgh: Herwt-Wat University Press.

Harmens, H., Buse, A., Buker, P., Norris, D., Mills, G., Williams, B., ... Steinnes, E. (2004). Heavy metal concentration in European mosses: 2000/2001 survey. Journal of Atmospheric Chemistry, 49, 425-436. http://dx.doi.org/10.1007/s10874-004-1257-0

Howard, I. C., Horsefall, M., Spiff, I. A., \& Teme, S. C. (2006). Heavy metals levels in surface waters and sediments in an oil field in the Niger Delta, Nigeria. Global Journal of Pure and Applied Sciences, 12(1), 79-83. http://dx.doi.org/10.4314/gjpas.v12i1.16570

Khandekar, R. N., Kelkar, D. N., \& Vohra, K. G. (1979). Lead, cadmium, zinc, copper and iron in the atmosphere of Greater Bombay. Atmospheric Environment, 14, 457-461. http://dx.doi.org/10.1016/0004-6981(80)90210-3

Kim, G., Scudlark, J. R., \& Church, T. M. (2000). Atmospheric wet deposition of trace elements to Chesapeake $\begin{array}{lllll}\text { and Delaware } \quad \text { Bays. Atmospheric } & \text { Environment, 34, 34-3444. }\end{array}$ http://dx.doi.org/10.1016/S1352-2310(99)00371-4

Koch, M., \& Rotard, W. (2001). On the contribution of background sources to heavy metal content of municipal sewage sludge. Water Science Technology, 43, 67-74.

Langerweff, I. V., \& Specht, A. W. (1970). Contamination of roadside soil and vegetation with cadmium, nickel, lead and zinc. Environmental Science Technical, 4, 583-586. http://dx.doi.org/10.1021/es60042a001 
Magas, O. K., Gunter, J. T., \& Regens, J. L. (2007). Ambient air pollution and daily pediatric hospitalizations for asthma. Environmental Science and Pollution Research, 14, 19-23. http://dx.doi.org/10.1065/espr2006.08.333

McDonald, C., \& Duncan, H. J. (1979). Atmospheric levels of trace elements in Glasgow. Atmospheric Environment, 13, 413-417. http://dx.doi.org/10.1016/0004-6981(79)90298-1

Mucha, A. P., Vasconcelos, M. T. S. D., \& Bordalo, A. A. (2003). Macrobenthic community in the Doura estuary: relations with trace metals and natural sediment characteristics. Environ. Pollut., 121, 169-180. http://dx.doi.org/10.1016/S0269-7491(02)00229-4

Muller, G. (1969). Index of geoaccumulation in sediments of the Rhine River. Geol. J., 2, 109-118.

NRC (National Research Council). (1985). Oil in the Sea: Inputs, Fates and Effects. Washington: National Academy Press.

Nwadinigwe, C. A., \& Nwaorgu, O. N. (1999). Metal contaminants in some Nigerian well-head crudes: comparative analysis. Journal of the Chemical Society of Nigeria, 24, 118-121.

Obasohan, E. E., \& Oronsaye, J. A. O. (2000). Heavy metals in water, sediments and some important fish species from Ikpoba River, Benin City, Nigeria. Journal of Applied Science and Environment Management, 42, 63-68.

Ogri, O. R., Obi-Abang, M., \& Uyana, D. A. (2000). Trace metals in dust particulates from Calabar Municipality, Nigeria. Global Journal of Pure and Applied Sciences, 6(1), 137-142.

Ogri, O. R., Tabe, N. N., \& Eja, M. E. (2007). Trace metals and total hydrocarbon levels in soil and biota of a seasonal wetland drained by municipal runoff from Calabar, Cross River State, Nigeria. Global Journal of Pure and Applied Sciences, 13(3), 395-401. http://dx.doi.org/10.4314/gjpas.v13i3.16726

Okuo, J. M., \& Okolo, P. O. (2011). Levels of As, Pb, Cd and Fe in suspended particulate matter (spm) in ambient air of artisan workshops in Benin City, Nigeria. Bayero Journal of Pure and Applied Sciences, 4(2), 97-99.

Olumayede, E. G., Okuo, J. M., Ukpebor, E. E., \& Oviawe, A. P. (2008). Temporal and spatial variations of benzene in the atmosphere. Journal of Chemical Society of Nigeria, 33(2), 42-45.

Osibanjo, O., Kakulu, S. E., \& Ajayi, S. O. (1984). Trace metals in crude oils. Analyst, 109, 127-131. http://dx.doi.org/10.1039/an9840900127

Pacyna, J. M., \& Pacyna, E. G. (2001). An assessment of global and regional emissions of trace metals to the atmosphere from anthropogenic sources worldwide. Environmental Reviews, 9, 269-298. http://dx.doi.org/10.1139/a01-012

Prieditis, H., \& Adamson, I. Y. R. (2002). Comparative pulmonary toxicity of various soluble metals found in urban particulate dusts. Experimental Lung Research, 28, 563-576. http://dx.doi.org/10.1080/01902140290096782

Schiff, K. C., \& Weisberg, S. B. (1999). Iron as a reference element for determining trace metal enrichment in Southern California coast shelf sediments. Mar. Environ. Res., 48, 161-176. http://dx.doi.org/10.1016/S0141-1136(99)00033-1

Simoneit, B. R. T., Cox, R. E., \& Standley, L. J. (1988). Organic matter of the troposphere IV. Lipids in harmattan aerosols in Nigeria. Atmospheric Environment, 22(5), 981-1004. http://dx.doi.org/10.1016/0004-6981(88)90276-4

Taylor, S. R., \& McLennan, S. M. (1995). The geochemical evolution of the continental crust. Review of Geophysics, 33, 241-265. http://dx.doi.org/10.1029/95RG00262

Turekian, K. K., \& Wedepohl, K. H. (1961). Distribution of the elements in some major units of the earth's crust. Geol. Soc. Am., 72, 175-192. http://dx.doi.org/10.1130/0016-7606(1961)72[175:DOTEIS]2.0.CO;2

Usman, S. (2007). Nigeria: Scorching the Resource Curse. A paper presented at the London School of Economics and Political Science by Nigeria's Minster of Finance. TELL, 7, 33.

Uzoekwe, S. A., Ukpebor, E. E., \& Ahonkhai, S. I. (2008). Air quality assessment in a crude oil producing community with a flow station. Journal of Chemical Society of Nigeria, 33(2), 168-174.

Wild, P., Bourgkard, E., \& Paris, C. (2009). Lung cancer and exposure to metals: the epidemiological evidence. Method Molecular Biology, 472, 139-167. http://dx.doi.org/10.1007/978-1-60327-492-0_6 
World Bank. (1995). Defining an environmental development strategy, for the Niger Delta. Industry and Energy Operations Division. West Central Africa Department.

World Health Organization (WHO). (2006). Air Quality Guidelines for Particulate Matter, Ozone, Nitrogen dioxide and Sulfur dioxide: Global Update, 2005. Geneva, Switzerland.

World Health Organization (WHO). (2000). Guidelines for Air Quality. Geneva: World Health Organization.

Wu, G., Xu, B., Yao, T., Zhang, C, \& Gao, S. (2009). Heavy metals in aerosol samples from the Eastern Pamirs collected 2004-2006. Atmospheric Research, 93, 784-792. http://dx.doi.org/10.1016/j.atmosres.2009.03.011

Zhang, J., \& Liu, C. L. (2002). Riverine composition and estuarine geochemistry of particulate metals in China-Weathering features, anthropogenic impact and chemical fluxes. Estuar. Coast. Shelf S., 54, 1051-1070. http://dx.doi.org/10.1006/ecss.2001.0879 